\title{
Small Water Bodies in the Valley of the River Rudawa in Krakow - the Environmental Value ${ }^{* *}$
}

\section{Introduction}

Small water bodies (SWB), both artificial and natural, are nowadays often called oczka wodne in the whole country. This term originally referred only to natural, water-filled depressions in the terrain after glaciation in northern Poland [17]. The Act on Protection of Agricultural and Forest Land defines ponds as "natural, field and forest water bodies up to 1 ha" [23]. Such water basins are a common part of the landscape of northern Poland, while in southern Poland small natural water bodies are very rare $[1,13,16,25]$. Ponds fulfill a number of very important natural functions. They are an important element of environmental biodiversity. In recent years, therefore, more attention has been paid to the protection of SWB. Protection is possible also thanks to the Act on Protection of Agricultural and Forest Land, which includes ponds in the category of protected agricultural lands [23]. Small water bodies located within urban agglomerations and industrial areas are especially susceptible to degradation and devastation. Many similar entities have been permanently eradicated in Krakow in recent years - mostly due to urban pressure and lack of conservation action. The complex of ponds associated with the valley of the River Rudawa is one discreditable example.

The valley of the River Rudawa is located in the western part of Krakow agglomeration. The valley is valuable in terms of nature, landscape and recreation. However, this area is subject to very strong human pressure, mainly the expansion of urban infrastructure and, to a lesser extent, industrial building. The River Rudawa is a left tributary of the Vistula River. The riverbed was regulated in the early 20th century. The Rudawa previously flowed through a number of natural and artificial

* AGH University of Science and Technology, Faculty of Mining Surveying and Environmental Engineering, Department of Environmental Management and Protection, Krakow, Poland

** The study was performed in the Department of Environmental Management and Protection and financed by research project no. 11.11.150.008. 
riverbeds, forming numerous meanders. Oxbow lakes were remnants of these small water courses. Some of their isolated fragments remain, in the form of ponds. However, most of them have been eradicated by natural shallowing processes or human activities [2, 6, 12]. In the 1960s there were at least 10 natural and artificial ponds in the valley of the Rudawa in the area of Krakow agglomeration. Currently, there are only 3 ponds, including one in a state of near-disappearance. Still, these water bodies are an important element of biodiversity of the natural environment of the city.

The aim of this study is the environmental inventory, assessment of the conservation status and environmental conditions, as well as the identification of opportunities for legal protecting of SWB in the valley of the River Rudawa in the area of Krakow. The subjects of the study were all natural and artificial ponds with a surface not exceeding 1 hectare, and the remains of ponds that had disappeared due to shallowing and anthropopression.

\section{The Study Area}

The area surrounding the valley of the River Rudawa is characterized by a highly valued natural environment. Cultivated and fallowland, scrubland, ornamental and allotments (gardens for use by flat-dwellers) have the main share of land use. However, this area is also increasingly built over by residential and service buildings. The part of the river valley within the city boundaries is located in the buffer zone of the Bielańsko-Tyniecki Landscape Park. The Rudawa valley is located within the south-eastern part of the proposed area of the ecological network ECONET PL - labeled 16K (Kraków Area). The riverbed is an important element of ecological relationships, and forms a regional wildlife corridor. The residues of the Młynówka Królewska riverbed, located about 300-400 m distant, form a local wildlife corridor.

Geomorphology of the study area indicates that it is a proglacial Vistula valley, consisting of quaternary deposits [10]. The area is almost flat, sloping slightly towards the south. The Rudawa riverbed at the border of Rząska and Krakow is at an altitude of $212 \mathrm{~m}$ a.s.l. and, at the confluence to the Vistula, about $200 \mathrm{~m}$ a.s.l. The area is located on the boundary of the Silesian-Krakow Monocline and Carpathian Foredeep. Tertiary tectonic disturbances led to a number of fault structures. There are three structures in the study area: in the south - a horst of Sowiniec Hill with exposures of Jurassic rocks, a graben of Rudawa, and in the north, a block of Pasternik with exposures of Jurassic and Cretaceous rocks. Lithologically, the area is built of the following deposits: Quaternary silt, gravel, sand and alluvial soil forming the Rudawa valley, Tertiary clays and Jurassic limestone and marl [4, 22].

Surface waters in the study area include flowing waters, comprising the Rudawa, its tributary Potok Olszanicki and the periodic artificial watercourse Młynowka Królewska. There are also standing waters in the form of natural or artificial SWB. 
There are sand-gravel Quaternary and Jurassic aquifers in limestones and marls. Quaternary aquifer is supplied mainly by precipitation as well as from Jurassic aquifer. The groundwater level is at a depth of about $0.6 \mathrm{~m}$ below the ground. It has a tendency to rise during snowmelt and heavy rainfalls $[4,26]$. This influences water level variability in SWB.

A large part of the area is used by man. This has led to the transformation of soil. Soils have been partially covered or removed, mostly in places where buildings and infrastructure were constructed. The area contains alluvial soils (Fluviosols) and anthropogenic soils (Anthrosols). Exact Alluvial (Haplic Fluviosols) and brown alluvial (Cambic Fluviosols) are found mainly in the western part of the area. Anthropogenic soils are in the eastern part. These are usually built-up areas and urban soil (Urbisols), garden soil (Hortisols) as well as soil changed by the industry (Technosols) [20].

Semi natural communities is the main vegetation occurring in the study area. It is characterized by a rich grassy-herbaceous undergrowth and numerous shrubs and trees. Garden plants such as asters (Aster sp.) as well as garden shrubs and trees like walnut (Juglans regia) or the white snowberry (Symphoricarpos albus) have spread beyond the areas of cultivation of allotments and gardens. Willows (Salix sp.), alders (Alnus sp.), and white and black poplars (Populus alba, Populus nigra) form the top level of plant consolidation of the Rudawa riverbed and at the edges of ponds. Individual old willows (Salix sp.) occur mainly in the channel of the Młynówka Królewska riverbed. These trees act as wildlife corridors and a habitat for fauna. The plant communities in the study area comprise riverine fringe communities with golden rod and other species (Convolvuletalia sepium), scrub, fallow lands, lawns, squares and street greenery, cultivated greenery, allotment gardens and orchards, fields and orchard communities, domestic gardens and investment sites [4, 5, 11]. A rich mixture of habitats is found in areas adjacent to the Rudawa valley; these areas are also valuable in terms of the natural occurrence of animals, among which are protected species. The valley of the River Rudawa, as an important wildlife corridor, has a substantial impact on the diversity of fauna. Carabus (Carabus spp.), bumblebee (Bombus spp.), green woodpecker (Picus viridis), thrush nightingale (Luscinia luscinia), house sparrow (Passer domesticus), black redstart (Phoenicurus ochruros), northern white-breasted hedgehog (Erinaceus roumanicus), red squirrel (Sciurus vulgaris), weasel (Mustela nivalis) are among the strictly protected animal species found there. Examples of fauna under species protection are Burgundy snail (Helix pomatia) and European mole (Talpa europaea). It should be emphasized that the area around the Rudawa and the nearby water reservoirs are suitable for amphibians' breeding and living. All species of amphibians are protected in Poland. Common toad (Bufo bufo), common water frog (Rana esculenta) and pool frog (Rana lessonae) are species living in this area. Apart from the above-mentioned protected species in the area, there often occur mallard duck (Anas platyrhynchos), common pheasant (Phasianus colchicus), as well as small rodents and occasionally also grey partridge (Perdix perdix) and European hare (Lepus europaeus) [4, 11, 15]. 
The River Rudawa is an upland river with a relatively high proportion of groundwater feed (about $60 \%$ ). Therefore, annual fluctuations of the water level are lower than in mountain rivers. The regime of the river is based on rain and ground water as well as on snowmelt [4]. The total length of Rudawa is $35.8 \mathrm{~km}$. The last $8 \mathrm{~km}$ of its lower course are within the Kraków agglomeration. The Rudawa drains the north-western part of the city. River training and hydrotechnic constructions (embankments) of the River Rudawa in the city were carried out at the beginning of 20th century [19].

Among tributaries of the river Rudawa within the study area, Olszanicki Stream should be mentioned. It is a right-bank tributary of the Rudawa. In Olszanica, the stream creates a small valley, overgrown with trees and bushes, which is a local wildlife corridor. The areas along the creek are an ecological link between the Bielańsko-Tyniecki and Tenczyński landscape parks.

Młynówka Królewska (the Royal Millrace) was the most important of the artificial branches of the River Rudawa. Occasionally, during flood flow, residues of the channel are filled with water from the Rudawa. The most valuable natural asset of the preserved fragment of riverbed is the riparian forest formed by single old alders and willows $[4,6,11]$.

Standing waters in the study area are represented by several small water reservoirs. These are discussed in detail further in this document. In addition, a fish ponds complex, the Experimental Station of the Department of Ichthyobiology and Fisheries, University of Agriculture in Krakow is located in the immediate vicinity of the research area, at Mydlniki and Rząska.

The complex consists of 51 experimental ponds with a total water surface area of 26 hectares. The water supply channel from the left bank of the Rudawa delivers fresh water to the ponds. The fish ponds complex, due to the ecological relations with the waters that are the subject of this paper, is a significant extension of the network of surface water in this part of Krakow. These ponds form an important wildlife corridor, and the area has been proposed to be a part of the nature protection system as an "ecological site".

Other standing water bodies in the research site include several newly-created garden ponds on private properties. Two of these ponds have an area of several hundred square meters.

Among other former water reservoirs, two manor ponds in Chełm in Wola Justowska (near Podłużna Street) have played an environmentally significant function [7]. These ponds were situated on a watercourse which was a right tributary of the Rudawa. The ponds in Chelm were located in the middle of the way connecting the Rudawa oxbow lakes and reservoirs in Las Wolski (near Pod Sowińcem Street). The manor ponds probably played a similar ecological function to the above-mentioned complex of University of Agriculture in Krakow ponds, and provided a natural link between the reservoirs in the research area and the ponds located in Las Wolski. 


\section{Methods}

Water reservoirs can be classified according to various criteria $[8,9,17]$. The environmental assessment of the SWB was performed according to the following properties:

- location;

- surrounding area: terrain morphology (flat/ hummocky: concave forms, basin and valley, structure of land use around the reservoir);

- origin: natural (karst lake, oxbow lake), anthropogenic;

- morphometry: surface, size, length of the shoreline (estimated on the basis of orthophotomap [14]), depth $(<0.5 \mathrm{~m}$ or $>0.5 \mathrm{~m})$, the configuration of the scarp presented by percentage of inclination classified in four groups (0-25\%, $26-50 \%, 51-75 \%, 76-100 \%)$ and an occurrence of shallows;

- type of water body (perennial, periodic, dried reservoir);

- type of reservoir (without inflow, with inflow, flow-through);

- the extent of free water (in percents of free water, classified as following groups: $0-25 \%, 26-50 \%, 51-75 \%, 76-100 \%)$;

- insolation of the site (in percents, classified as following groups: $0-25 \%$, $26-50 \%, 51-75 \%, 76-100 \%)$;

- the distance to the nearest water bodies;

- the distance to the River Rudawa;

- water vegetation: amphiphyte (wet meadows - sedge, wetland plants), helophyte (plants growing at a maximum distance $1.5 \mathrm{~m}$ from the shore), nymphoides (plants with floating leaves), elodeids (plants completely submerged in water);

- coastal vegetation;

- synanthropisation of flora;

- shallowing and overgrowing processes (occur/not occur).

\section{Results and Discussion}

Based on the proposed inventory methodology, three existing water reservoirs were characterised. Numbers 1, 5 and 6 were given to these ponds (Fig. 1). In addition, the location of seven no-longer-existing features was marked on the map. Five of them were natural oxbow lakes on old fragments of the River Rudawa (nos. 2, 3, 4, 8 and 10) and two others had an anthropogenic genesis (nos. 7 and 9).

The SWB included in this study are listed below:

1. Pond in Mydlniki between Młynówka Królewska and the church in Mydlniki (Tab. 1).

2. Oxbow lake on the right bank of the Rudawa, near the railway track (non-existent) (Fig. 4). 
3. Oxbow lake on the left bank of the Rudawa, near Zakliki z Mydlnik Street, in the area of the Experimental Station in Mydlniki of the University of Agriculture in Krakow, Department of Vegetable and Herbal Plants (non-existent).

4. Oxbow lake of the Rudawa between Pylna and Beck Streets - west pond (non-existent).

5. Oxbow lake of the Rudawa between Pylna and Beck Streets - central pond, marked as $5 \mathrm{a}$ and $5 \mathrm{~b}$ (Tab. 1).

6. Oxbow lake of the Rudawa between Pylna and Beck Streets - east pond (Tab. 1).

7. Pound on the left bank of the Rudawa, near Jesionowa Street (non-existent).

8. Oxbow lake on the right bank of the Rudawa, between the Rudawa riverbed and Ludmiła Korbutowa Street (non-existent).

9. Pond between Hamernia and Odlewnicza Streets, about $40 \mathrm{~m}$ west of Odlewnicza Street (non-existent).

10. Oxbow lake on the left bank of the Rudawa, on north from Mydlnicka Street (non-existent).

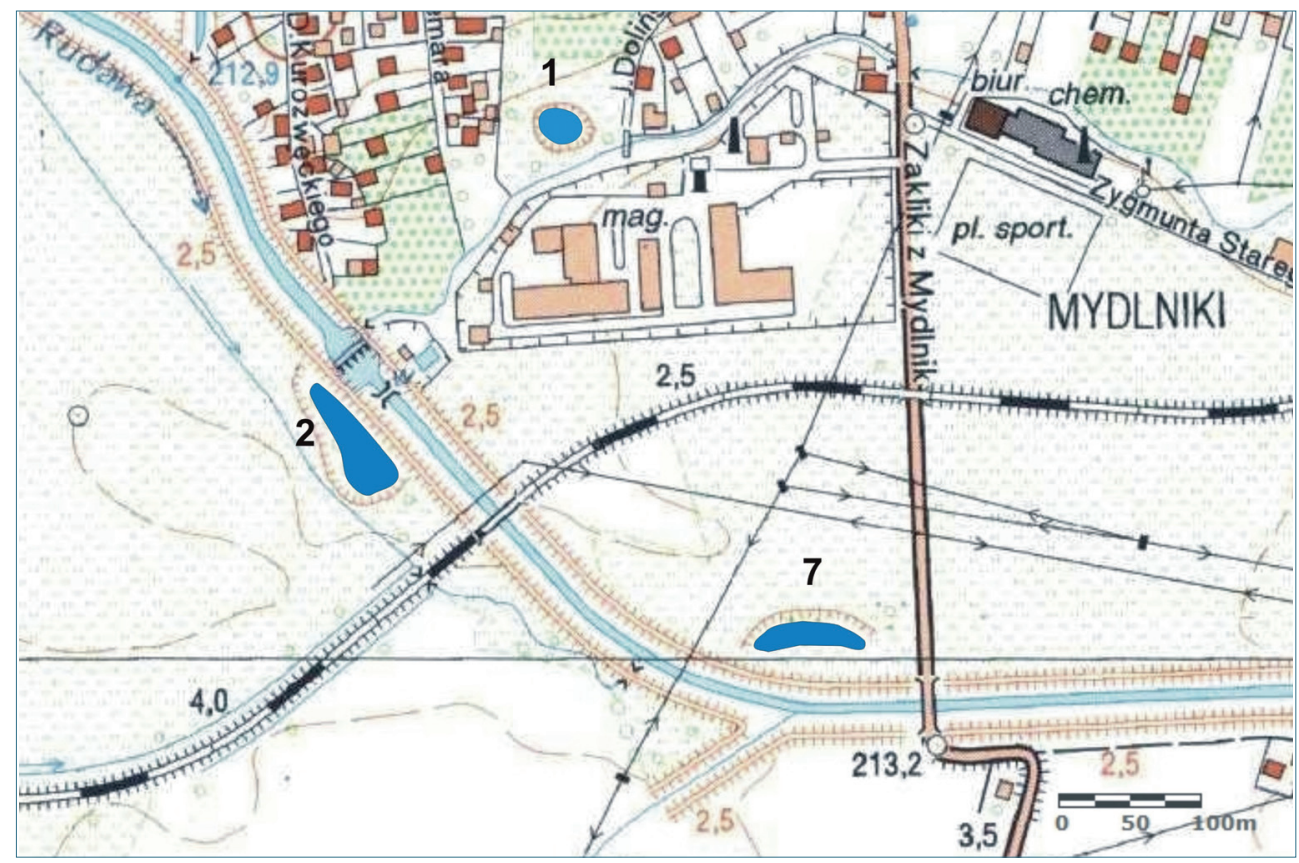

Fig. 1. Location of ponds 1, 2 and 7

Source: own study based on the map from geoportal.gov.pl

The pond in Mydlniki (no. 1) is one of still existent water bodies. This SWB is located between the dried riverbed of Młynówka Królewska and the church in Mydlniki (Fig. 1). The reservoir is partly a natural pond, formed as a result of karst 
processes. Two more existent water reservoirs are remains of the old river bed of the River Rudawa (Fig. 2).

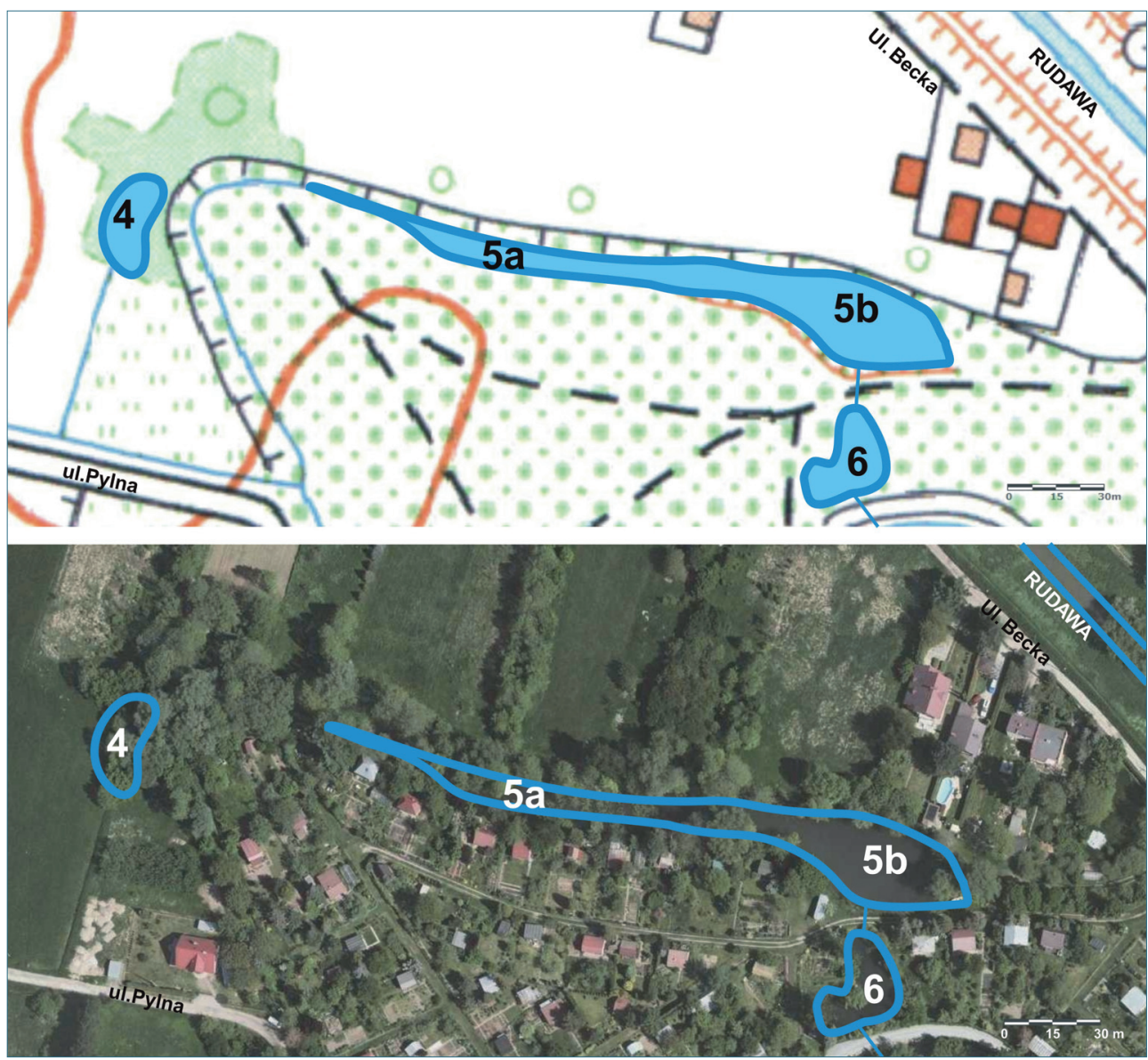

Fig. 2. River Rudawa oxbow lake complex located between Pylna and Beck Streets - location of ponds $4,5 \mathrm{a}, 5 \mathrm{~b}$ and 6

Source: own study based on the map from geoportal.gov.pl

This oxbow lake complex is located between Pylna and Beck Streets (nos. 5 and 6). The largest pond is a central, open water reservoir (no. 5b). The reservoir no. $5 \mathrm{a}$ is separated from the open water by a dyke. This natural, old riverbed of the River Rudawa is partially filled with water, but in part, it is only a wetland. The smaller open water pond (no. 6), located entirely within an area of allotments, is also a remnant of a Rudawa oxbow. The pond is connected by a sluice with pond no. $5 \mathrm{~b}$. Another sluice, located at Marynarska Street, connects the reservoir with a drainage ditch. 
Table 1. The environmental assessment of the still existent SWB in the valley of the River Rudawa

\begin{tabular}{|c|c|c|c|c|}
\hline No of SWB & 1 & $5 a$ & $5 b$ & 6 \\
\hline Location (street) & Dolińskiego Street & $\begin{array}{l}\text { Pylna and Beck } \\
\text { Streets }\end{array}$ & $\begin{array}{c}\text { Pylna and Beck } \\
\text { Streets }\end{array}$ & Marynarska Street \\
\hline $\begin{array}{l}\text { Surrounding } \\
\text { area terrain } \\
\text { morphology }\end{array}$ & flat & flat & flat & flat \\
\hline $\begin{array}{l}\text { Structure of } \\
\text { land use }\end{array}$ & $\begin{array}{c}\text { grassland area } \\
\text { (meadow, } \\
\text { orchard) which } \\
\text { is surrounded by } \\
\text { detached houses } \\
\text { and an industrial } \\
\text { area }\end{array}$ & $\begin{array}{l}\text { allotments, } \\
\text { meadows, } \\
\text { fallowlands }\end{array}$ & $\begin{array}{l}\text { allotments, } \\
\text { single-family houses }\end{array}$ & allotments \\
\hline Origin & $\begin{array}{l}\text { karst lake / } \\
\text { antropogenic }\end{array}$ & oxbow lake & $\begin{array}{l}\text { oxbow lake / } \\
\text { antropogenic }\end{array}$ & $\begin{array}{l}\text { oxbow lake/ } \\
\text { antropogenic }\end{array}$ \\
\hline Surface $\left[\mathrm{m}^{2}\right]$ & 500 & 500 & 2,500 & 500 \\
\hline Length $[\mathrm{m}]$ & 30 & 50 & 140 & 25 \\
\hline Width [m] & 30 & $1-10$ & $10-30$ & 30 \\
\hline Depth $[\mathrm{m}]$ & $<0.5$ & $<0.5$ & $>0.5$ & $>0.5$ \\
\hline $\begin{array}{l}\text { Length of the } \\
\text { shoreline [m] }\end{array}$ & 100 & 120 & 330 & 110 \\
\hline $\begin{array}{l}\text { Inclination of } \\
\text { the scarp [\%] }\end{array}$ & $51-75$ & $\begin{array}{l}\text { 0-25 (north bank) - } \\
51-75 \text { (south bank) }\end{array}$ & $\begin{array}{l}\text { 0-25 (north bank) - } \\
51-75 \text { (south bank) }\end{array}$ & $51-75$ \\
\hline $\begin{array}{l}\text { High of the } \\
\text { scarp [m] }\end{array}$ & $0.5-0.7$ & $\begin{array}{c}0.2 \text { (north bank) - } \\
1.0 \text { (south bank) }\end{array}$ & $\begin{array}{c}0.2 \text { (north bank) }-1.0 \\
\text { (south bank) }\end{array}$ & $0.5-0.7$ \\
\hline Shallows & not occur & occur & not occur & not occur \\
\hline $\begin{array}{l}\text { Type of water } \\
\text { body }\end{array}$ & perennial & perennial & perennial & perennial \\
\hline $\begin{array}{l}\text { Type of } \\
\text { reservoir }\end{array}$ & without inflow & without inflow & without inflow & flow-through \\
\hline \begin{tabular}{|l} 
Extent of free \\
water [\%]
\end{tabular} & $76-100$ & $51-75$ & $76-100$ & $76-100$ \\
\hline \begin{tabular}{|l} 
Insolation \\
conditions [\%]
\end{tabular} & $76-100$ & $51-75$ & $51-75$ & $76-100$ \\
\hline $\begin{array}{l}\text { Distance to } \\
\text { nearest water } \\
\text { bode }[\mathrm{m}]\end{array}$ & 300 & 1 & 1 & 4 \\
\hline $\begin{array}{l}\text { Distance to the } \\
\text { river Rudawa } \\
{[\mathrm{m}]}\end{array}$ & 200 & 180 & 90 & 120 \\
\hline
\end{tabular}


Table 1. cont

\begin{tabular}{|c|c|c|c|c|}
\hline $\begin{array}{l}\text { Water } \\
\text { vegetation }\end{array}$ & $\begin{array}{l}\text { yellow iris (Iris } \\
\text { pseudacorus), } \\
\text { wood club-rush } \\
\text { (Scirpus sylvaticus), } \\
\text { common rush } \\
\text { (Juncus effusus) }\end{array}$ & $\begin{array}{l}\text { wood club-rush } \\
\text { (Scirpus sylvaticus), } \\
\text { yellow iris (Iris } \\
\text { pseudacorus), } \\
\text { common reed } \\
\text { (Phragmites } \\
\text { australis) }\end{array}$ & $\begin{array}{l}\text { wood club-rush } \\
\text { (Scirpus sylvaticus), } \\
\text { narrowleaf cattail } \\
\text { (Typha angustifolia) } \\
\text { and yellow iris (Iris } \\
\text { pseudacorus), garden } \\
\text { varieties of water-lily } \\
\text { (Nymphaea sp.) }\end{array}$ & $\begin{array}{l}\text { yellow iris (Iris } \\
\text { pseudacorus), } \\
\text { wood club-rush } \\
\text { (Scirpus } \\
\text { sylvaticus), } \\
\text { common rush } \\
\text { (Juncus effusus), } \\
\text { garden varieties } \\
\text { of water-lily } \\
\text { (Nymphaea sp.) }\end{array}$ \\
\hline $\begin{array}{l}\text { Coastal } \\
\text { vegetation }\end{array}$ & $\begin{array}{l}\text { old willows } \\
\text { (Salix sp.) } \\
\text { and poplars } \\
\text { (Populus sp.) }\end{array}$ & $\begin{array}{l}\text { silver birch trees } \\
\text { (Betula pendula) and } \\
\text { Norway spruce } \\
\text { (Picea abies), } \\
\text { Alder thicket (Alnus } \\
\text { sp.) with a few } \\
\text { single old willows } \\
\text { (Salix sp.) }\end{array}$ & $\begin{array}{l}\text { silver birch trees } \\
\text { (Betula pendula) and } \\
\text { Norway spruce (Picea } \\
\text { abies) }\end{array}$ & $\begin{array}{l}\text { silver birches } \\
\text { (Betula pendula), } \\
\text { white willow } \\
\text { (Salix alba) }\end{array}$ \\
\hline $\begin{array}{l}\text { Synanthropisa- } \\
\text { tion of flora }\end{array}$ & $\begin{array}{l}\text { garden shrubs and } \\
\text { herbaceous plants }\end{array}$ & not occur & $\begin{array}{l}\text { ruderal plants: } \\
\text { common nettle } \\
\text { (Urtica dioica), } \\
\text { blackberry (Rubus } \\
\text { sp.) and raspberry } \\
\text { (Rubus idaeus) }\end{array}$ & $\begin{array}{l}\text { garden shrubs, } \\
\text { herbaceous plants } \\
\text { and lawns }\end{array}$ \\
\hline $\begin{array}{l}\text { Shallowing and } \\
\text { overgrowing } \\
\text { processes }\end{array}$ & occur & occur & not occur & not occur \\
\hline
\end{tabular}

The third of the Rudawa oxbow lakes complex, between Pylna and Beck Streets, (Fig. 3) is now completely dry. Decline of the water table was observed in the years 2009-2012 [1, 16]. The pond was located about $120 \mathrm{~m}$ from the present Rudawa riverbed.

a)

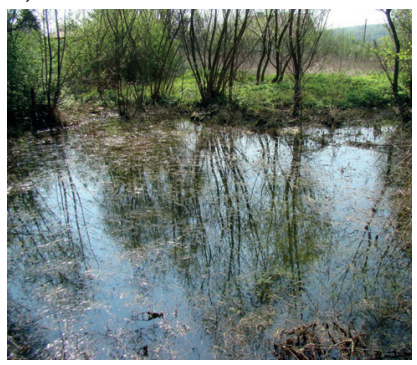

b)

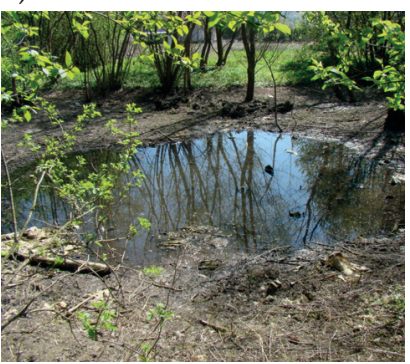

c)

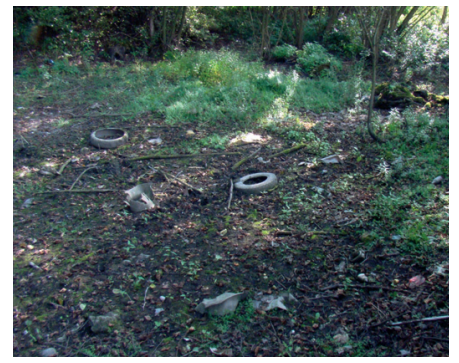

Fig. 3. Oxbow lake of the Rudawa between Pylna and Beck Streets - west pond; drying process of the pond in the years: 2009 (a), 2011 (b) and 2012 (c)

Source: [16] 
The other, no longer existing, water bodies in the study area are shallowed, dried out (no. 2 - Fig. 4, no. 4 and no. 7) and some have been backfilled (nos. 3, 8, 9 and 10). Until now only the remains of two water reservoirs have been preserved: the previously-mentioned reservoir no. 4 and the shallowed and dried basin of pond no. 9 .

Small ponds are especially vulnerable to various forms of anthropogenic pressure $[3,17,18,21]$. Only three of the ten ponds identified in the article are preserved and permanently filled with water (Tab. 1). Until recently, reservoir no. 4 "Oxbow lake of Rudawa between Pylna and Beck Streets - west pond" was periodically filled with water. Currently, the basin of the pond is shallow, dried and partly backfilled (Fig. 3).

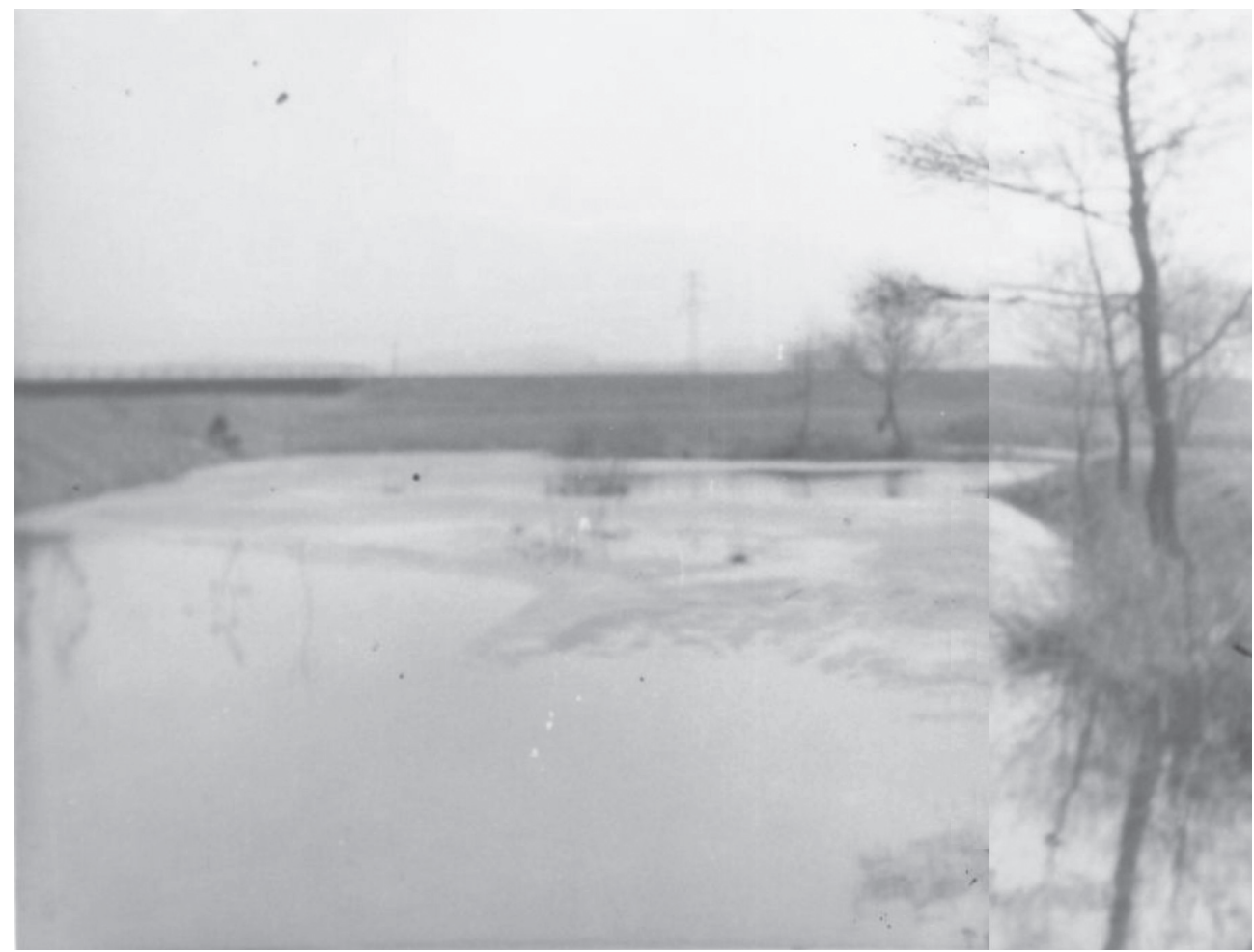

Fig. 4. A now non-existent oxbow lake on the right bank of the River Rudawa, near the railway track (no. 2); compilation of two archival photos from the late 60s

Photo: E. Panek

The largest of the existing reservoirs (no. 5, "Oxbow lake of the Rudawa between Pylna and Beck Streets - central pond") deserves special environmental protection. Characteristics such as: size, depth differentiation and insolation, the developed shoreline, and the shoreline vegetation represented by single, old willows (Salix sp.) and bushes, determine its considerable natural value. The water 
connection with reservoir no. 6 ("Oxbow lake of Rudawa between Pylna and Beck Streets - east pond") is also environmentally valuable. The location of the reservoir on a partially fenced area of allotments is convenient for conservation purposes. The western, natural, part of the reservoir requires active protection by deepening and stopping drainage works. Among the most important natural hazards are: anthropogenic destruction and backfill of the eastern part of the pond, in the vicinity of the road (Beck Street), and urban expansion (single-family houses and garden fencing). The previously mentioned infrastructure surrounding the reservoir from the north forms an ecological barrier and may ultimately lead to a loss of natural connection with the River Rudawa wildlife corridor.

Pond no. 1 in Mydlniki, between Młynówka Królewska and the church in Mydlniki, is environmentally isolated from the ponds discussed above due to its karst origin as well as distance. Although it is located within the grassland, there are ecological barriers in close proximity to the reservoir. Industrial areas (buildings, parking lots, roads) to the south and fenced building plots surrounding the pond from the north form a territorial barrier. Old willow (Salix sp.) and poplar (Populus sp.) trees increase the ecological value of the reservoir. The pond requires to be dredged and re-naturalized in order to become a valuable natural site for recreational purposes. The dry riverbed of the Młynówka Królewska is in the close vicinity of the pond. The millrace formerly was the natural connection between waterbodies as the local wildlife corridor.

\section{Conclusions}

In Western European countries where the processes of wetland degradation are more advanced, the water bodies are the object of nature conservation and protection. The activities comprise maintenance, re-naturalization and creation of small water bodies as valuable ecosystems.

The reservoirs mentioned in this study are located in the buffer zone of the Bielańsko-Tyniecki Landscape Park. However none of them is located within the legal protection area, which would enable conservation activation. Ponds no. 5 and 6 are the only existing fragments of the Rudawa oxbows in Krakow. Their preservation should be considered to preserve them by establishing an ecological site form of protection. Remains of natural ecosystems that are important for the preservation of biodiversity - including natural water bodies, field and forest ponds, oxbow lakes, clumps of trees and shrubs, swamps or wetlands, wasteland areas, habitats, refuges, reproduction areas, places of seasonal presence of rare or protected plants, animals and fungi species - may be preserved by the law form of ecological site. The oxbow complex fulfills the conservation requirements according to the Nature Conservation Act [24]. 


\section{References}

[1] Bedla D., Panek E.: Ecological and landscape valuation of small water bodies in the selected municipalities of the Małopolska province. Geomatics and Environmental Engineering, vol. 2, no. 4, 2008, pp. 59-68.

[2] Bieniarzówna J., Małecki J.M., Mitkowski J.: Kraków w latach 1918-1939. Dzieje Krakowa, t. 4, Wydawnictwo Literackie, Kraków 1997.

[3] Bosiacka B., Pieńkowski P.: Analiza przekształceń oczek wodnych oraz ocena walorów przyrodniczych śródpolnych zbiorników w centralnej części Równiny Nowogardzkiej. Woda-Środowisko-Obszary Wiejskie, t. 4, z. 2a, 2004, pp. 335-349.

[4] Dejko M.: Miejscowy Plan Zagospodarowania Przestrzennego Obszaru "Młynówka Królewska - Zygmunta Starego" Prognoza oddziaływania na środowisko. Urząd Miasta Krakowa, Biuro Planowania Przestrzennego, Kraków 2012.

[5] Dubiel E., Szwagrzyk J. (red.): Atlas roślinności rzeczywistej Krakowa. Urząd Miasta Krakowa, Wydział Kształtowania Środowiska, Kraków 2008.

[6] Hebda-Małocha A., Małocha M.: Gospodarcza rola Młynówki Królewskiej w Krakowie i jej wptyw na obecne zagospodarowanie miasta. Czasopismo Techniczne. Środowisko, r. 104, z. 2-Ś, 2007, pp. 123-134.

[7] Janczykowski J. (red.): Mapa twierdzy (1899-1904). Atlas Twierdzy Kraków. Seria 1, Materiały Źródłowe, t. 12, Urząd Miasta Krakowa, Oddział Ochrony Zabytków, Kraków 2000.

[8] Kajak Z.: Hydrobiologia-limnologia. Ekosystemy wód śródlądowych. Wydawnictwo Naukowe PWN, Warszawa 1998.

[9] Klafs G., Jeschke L., Schmidt H.: Genese und Systematyk wasserführender Ackerhohlformen in den Nordbezierken der DDR. Archiv für Naturschutz und Landschaftsforschung, Bd. 13, 4, 1973, pp. 287-302.

[10] Klimaszewski M. (red.): Kraków - środowisko geograficzne. Folia Geographica. Series Geographica-Physica vol. 8, Państwowe Wydawnictwo Naukowe, Warszawa - Kraków 1974.

[11] Kostuch R., Maślanka K.: Ewenement niespotykany - Młynówka Królewska dziś. Aura, nr 9/2003, 2003, pp. 22-24.

[12] Marczykiewicz F.: Hidrografia miasta Krakowa i jego okręgu. Drukarnia Uniwersytecka UJ, Kraków 1847.

[13] Nowacka-Rejzner U.: Stawy i tereny podmokłe w obszarze miasta. Czasopismo Techniczne. Architektura, r. 104, z. 7-A, 2007, pp. 127-134.

[14] Ortophotomap, [on-line:] geoportal.gov.pl/imap/ [access: March 2014].

[15] Palaczyk A., Połczyńska-Konior G., Przybyłowicz Ł.: Opracowanie kompleksowej inwentaryzacji płazów $i$ ich miejsc rozrodu w granicach administracyjnych Miasta Krakowa. Instytut Systematyki i Ewolucji Zwierząt PAN, Kraków 2010.

[16] Panek E., Rajpolt B.: Preliminary studies on the protecting possibilities of selected small water bodies in the area of Krakow agglomeration. Geomatics and Environmental Engineering, vol. 7, no. 2, 2013, pp. 43-57. 
[17] Pieńkowski P.: Analiza rozmieszczenia oczek wodnych oraz zmian w ich występowaniu na obszarze Polski pótnocno-zachodniej. Akademia Rolnicza, Szczecin 2003.

[18] Piesik J.: Małe zbiorniki wodne w krajobrazie Szczecina. Nauka Przyroda Technologie, t. 3, z. 1, 2009, pp. 1-10.

[19] Pociask-Karteczka J.: Przemiany stosunków wodnych na obszarze Krakowa. Zeszyty Naukowe Uniwersytetu Jagiellońskiego. Prace Geograficzne, z. 96, 1994, pp. 7-53.

[20] Skiba S., Drewnik M., Szymański W., Żyła M.: Mapa gleb miasta Krakowa 1:20 000. Uniwersytet Jagielloński, Instytut Geografii i Gospodarki Przestrzennej, Zakład Gleboznawstwa i Geografii Gleb, Kraków 2008, [on-line:] http:// planowanie.um.krakow.pl/bppzoom/index.php?ID=95 [access: 11 March 2014].

[21] Surmacki A.: Zagrożenia małych zbiorników śródpolnych na Pomorzu Zachodnim. Chrońmy Przyrodę Ojczysta, r. 54, z. 6, 1998, pp. 61-69.

[22] Szczegótowa mapa geologiczna Polski 1:50 000. 973. Arkusz Kraków. Państwowy Instytut Geologiczny, Wydawnictwa Geologiczne, Warszawa 1993.

[23] Ustawa z dnia 16 kwietnia 2004 r. o ochronie przyrody. Dz.U. 2013, poz. 627, 628, 842 [Journal of Laws 2013, items 627, 628, 842].

[24] Ustawa z dnia 18 lipca 2013 r. o ochronie gruntów rolnych i leśnych. Tekst jednolity: Dz.U. 2013, poz. 1205 [consolidated text: Journal of Laws 2013, item 1205].

[25] Wagner A.: The role of post-exploitation water ponds in the environment management of rural areas. Zeszyty Naukowe Akademii Rolniczej im. H. Kołłątaja w Krakowie, nr 404, Inżynieria Środowiska, z. 24, 2003, pp. 159-165.

[26] Wody powierzchniowe $i$ wody podziemne w Krakowie. BIP Miasto Kraków, Wydział Kształtowania Środowiska, [on-line:] https://www.bip.krakow. pl/?sub_dok_id=20375, 2009 [access: 03 March 2014]. 